\title{
Developing Instruction Materials Based on Joyful PBL to Improve Students Mathematical Representation Ability
}

\author{
Ani Minarni ${ }^{1} \&$ E. Elvis Napitupulu ${ }^{1}$ \\ ${ }^{1}$ Mathematics Department, State University of Medan, Indonesia \\ Correspondence: Ani Minarni, Mathematics Department, State University of Medan, Indonesia. E-mail: \\ animinarni10@gmail.com
}

Received: March 1, 2017

Accepted: April 5, $2017 \quad$ Online Published: August 27, 2017

doi:10.5539/ies.v10n9p23

URL: https://doi.org/10.5539/ies.v10n9p23

\begin{abstract}
Solving problem either within mathematics or beyond is one of the ultimate goal students learn mathematics. It is since mathematics takes role tool as well as vehicle to develop problem solving ability. One of the supporting components to problem solving is mathematical representation ability (MRA). Nowadays, many teachers and researchers find out secondary school students are so poor in MRA. Considering the problem, this research developed instruction materials based on Joyful Problem-based learning (JPBL) to endorse eighth graders of public secondary school students grasp their MRA. The study took place in the Province of North Sumatera, Indonesia. A number of 88 students engaged as subjects. The study administered MRA test before and after implementing the instruction materials. Data is analyzed descriptively and by t-test. The result showed that the learning materials developed is effective in improving the students' MRA. It increased significantly, though categorized mediocre. The study contributed to the existing instruction materials in pursuing MRA.
\end{abstract}

Keywords: instruction materials, mathematical representation ability, joyful-PBL

\section{Introduction}

In contrast to the industrial era, the information and communication technology era requires individuals not only able to pass procedural activities but also able to reason or to think critically and creatively (higher order thinking skills, HOTs). This era needs thinker as well as inventor or creator more than labor at all. HOTs has characteristics such as non-algorithmic (the path of action is not fully specified in advance), tends to be complex, often yields multiple (ways) solutions, involves judgment and interpretation nuances, the application of multiple criteria. It often involves uncertainty, self-regulation of the thinking process, imposing meaning, finding structure in apparent disorder, and effortful (Hmelo and Ferrari, 1997; Resnick, 1987; Saragih \& Napitupulu, 2015). It makes sense whilst Baker (1990) emphasizes that HOTs measures constitute tasks demanding more than information retrieval and either procedural or conceptual understanding. It is so important then to take into account this competence as early as possible in the part of the students. Since by embracing the competence aforementioned they become potential thinker and problem solver.

One of the most important competencies constitutes HOTs is mathematical representation. As Cobb et al. (1992) asserted, "Many of the current attempts to develop theories in mathematics education reflect the view that learning is a process of constructing internal mental representations". The authors proceed arguing, "learning is a process in which students modify their internal mental representations to construct mathematical relationship or structures that mirror those embodied in external instructional representations". While, Pape and Tchosanov (2001) state that representation may be thought of broadly as mental states, narrowly be thought of as mental reproduction of mental state. A structural equivalent presentation through picture, symbol, or signs. Or 'something' in place of 'something'. According to theory of recognition and brain investigation, brain works more effectively while making representation patterns for encoding (internalizing) and decoding (externalizing) information.

Teachers can and should develop representation ability at school through learning process. One of the most responsible subjects to mediate and facilitate students grasping this requirement is mathematics. Therefore, the goals of school mathematics should be to teach students to think, to make them comfortable with problem solving, to help them pose questions and formulate hypotheses, investigate, and make mathematics vehicle to think (Kulm, 1990), as well as grasping representation ability (NCTM, 2000). 
The preliminary research carried out in 2015 (Minarni, Napitupulu, \& Husein, 2016) showed that learning in the classroom is still apparently without attempting to encourage students to contribute their own mathematical representation. This is reasonable, because expository method still dominated learning in the classroom and very rarely gives students chances to get involved in solving mathematical problems. Teacher still acts as the center of learning process in the classroom. Fogarty (1997) mentioned that such learning could not make the students fully understand what is learned. Yet understanding is a major component that enables students solving problem (Schöenfeld, 2007). Indeed, this kind of learning is not going to foster students' ability to solve problems since the students do not have opportunity to do so (Ronis, 2008).

Furthermore, observations and interviews in this preliminary study revealed the teachers' complaints on the lower secondary students' weakness in drawing pictures, creating table and building mathematical equation to represent mathematical problems. These skills are clearly aspects of mathematical representations. As known for a long time, mathematical representation ability supports problem-solving skill. Concerning this, it is then important to note suggestion Pape and Tchosanov (2001) posed that teachers and students must develop classroom norms that facilitate explanation and justification and the use of representations in the service of supporting argument.

\section{Theoretical Framework}

\subsection{Developmental Research}

The study is developmental in nature, which aimed at both developing innovative intervention and identifying underlying design principles or theories (Plomp, 2013). Innovative intervention includes implementing developed learning model and learning materials. Nieveen and Folmer (2013) distinguish four quality criteria that are applicable to a wide array of educational intervention (these criteria suggest a logical hierarchy):"

1) Relevance (also called content validity)

There is a need for the intervention and its design is based on state-of the art (scientific) knowledge.

2) Consistency (also called construct validity)

The intervention is 'logically' design.

3) Practicality

Expected: The intervention is expected to be usable in the settings for which it has been designed.

Actual: The intervention is usable in the settings for which it has been designed.

4) Effectiveness

Expected: Using the intervention is expected to result in desired outcome.

Actual: Using the intervention results in desired outcome".

\subsection{Mathematical Representation Ability}

"Representation is a configuration that can represent something else in some manner" (Goldin, 2002). People develop representations in order to interpret and remember their experiences in an effort to understand the world. Kilpatrick, Swafford, \& Findell (2001) stated that representation could be used to understand mathematics. Mathematics requires representations because of its abstract nature such that people have access to mathematical ideas only through the representation of those ideas.

Carpenter \& Lehrer (1999) classify representations into two categories, namely internal representation and external representation. Internal representation is everything that exists in the cognitive structure of students, while the external representation is pictures, tables, graphs, sketches, symbols, equation (mathematical model), words (verbal) made by the students as a reflection of internal representation.

Meira (2002) states that representations can bridge difficulties in understanding mathematics and can make mathematics more attractive and interesting (not rigid and monotonous). Representation is helpful in presenting problems more clearly and makes the students comprehend concepts or ideas of mathematics better. Representation enables students to create and use representation to organize, record, and communicate mathematical ideas; select, apply, and translate among mathematical representation to solve problems; use representation to model and interpret physical, social, and mathematical phenomena (NCTM, 2000).

Based on various meaning of representation above, it can be viewed that mathematical representation presented by the students in the form of figure, graph, table, equation (mathematical model), explanation in words or sentences that constitute word problem faced by the students, are pointed out representation in the cognitive 
structure of the students, vice versa.

\subsection{Joyful Problem-Based Learning}

Students' mathematical representation ability will grow by giving them chances to solve various mathematical problems since by solving mathematical problems they will grasp various mathematical representations (NCTM, 2000). One of the best moments for teachers giving students chances to solve various mathematical problems surely in the teaching and learning processes in the classrooms.

On the other side, Arends (2004) states that learning approach which is in accordance with the purpose mentioned earlier is problem-based learning (PBL) since it is designed to promote students' ability in mathematical problem solving. Problem solving requires five others mathematical ability i.e. mathematical comprehension (understanding), reasoning, connection, communication, and representation. Therefore, through solving problems students will develop their capabilities wholly in doing mathematics.

PBL begins with presenting students authentic and meaningful problem situation that can serve as springboards for investigation and inquiry. PBL integrate learning from different sources and disciplines through synthesis and collaborative inquiry. PBL respect the situation in which students are not sure about the data, information, as well as a solution, situation that students will face in real world. All students, regardless of their abilities, can benefit from PBL.

One important feature in PBL is a problem. Problem should be able to act as trigger in early learning and should be designed to improving high order thinking. Such problem can be designed by relating it to the characteristics of high order thinking which proposed by Resnick (1987).

Meanwhile, applying learning approach in eighth grade need considering the development of students' mental. At this age, students are in the transition from concrete to formal stage. Therefore, combining PBL with a joyful learning environment will lead the students feel comfortable and happy to learn mathematics. The idea is in line with Puri's (2014). In her work, she suggests that learning in the classroom should be made as interesting as game so that students addicted to learn as they addicted to play the game.

Joyful Problem-Based Learning is problem-based learning designed such that the learning activity conducted in pleasant environment and convenient situation. Sometimes learning is conducted outside the classroom and using a variety of hands-on manipulatives around the classroom or school yard, which is interesting for students; the teacher scaffolds the students with friendly language (tone of the teachers' voice, facial expression, body posture and gesture makes the child comfortable). The objects that exist inside and outside the classroom, as well as the environment around the classroom used as devices to increase the interest of students to learn, but the focus remains on efforts to lead the students making a variety of representations of a problem so they truly understand the subject matter at hand.

We presented in Table 1 learning activity follows the modified PBL in joyful learning environment.

The learning activity took place not only in the classroom, but also outside. For example, in solving the problems related to the topic of two-variable linear equation system, the students are invited to a bookstore located around the school area. At the bookstore, students learn to determine the price of goods sold such that the solution of problem-price become more meaningful. Meanwhile, for the problems related to Pythagorean rule, the students solved the problem in the classroom using hands-on manipulatives.

During conducting the lesson, the teacher should confirm that the students show their understanding on the problem, show the effort to represent it in the form that made it easier or aid them attaining the solution. Of course, the teacher, when needed, provides assistance or scaffolding to students who have difficulty in understanding the problem.

While working on problems in the students' activity sheet (SAS), teacher asked the students did it individually in time duration of 10 to 15 minutes. They at least attempted to grasp what information the problem gave and what it demanded. Then teacher asked them to work collaboratively, while teacher observed and gave scaffolding to who needed. 
Table 1. Syntax of modified problem-based learning

\begin{tabular}{|c|c|}
\hline Phase & Teacher Behavior \\
\hline $\begin{array}{l}\text { 1. Orient the students to the } \\
\text { problem }\end{array}$ & $\begin{array}{l}\text { - Inform objectives of the lesson } \\
\text { - Describe the important logical requirements } \\
\text { - Motivates students to engage in self-directed and problem-solving activity }\end{array}$ \\
\hline 2. Organize the students to learn & Helps students define and organize learn tasks related to the problem presented in SAS. \\
\hline $\begin{array}{l}\text { 3. Assist independent and group } \\
\text { Investigation }\end{array}$ & $\begin{array}{l}\text { - Encourage students to gather appropriate information, understand the problem (make various } \\
\text { appropriate representation as an aid to attain the solution), and search for explanations and solutions } \\
\text { - Give appropriate scaffolding to the students who could not move or develop their thinking in attempting } \\
\text { to solve problem. }\end{array}$ \\
\hline $\begin{array}{l}\text { 4. Develop and present artifacts } \\
\text { and Exhibits }\end{array}$ & $\begin{array}{l}\text { - Assists students in planning and preparing appropriate report associated with the solution they get to } \\
\text { the problem } \\
\text { - Help the students displaying their work on the white/black board } \\
\text { - Helps students share their work with others }\end{array}$ \\
\hline $\begin{array}{l}\text { 5. Analyze and evaluate the } \\
\text { problem-solving process }\end{array}$ & $\begin{array}{l}\text { Helps students to reflect on their investigation, using appropriate representations and the processes they } \\
\text { used to get the solution of the problems. }\end{array}$ \\
\hline
\end{tabular}

\section{Methodology}

\subsection{Subjects, Design, and Data Sources}

The subject of the research is the students from three public junior high school (PJHS) in the Province of North Sumatera, Indonesia. Of each, the researchers took one eight graders class. Totally, there are 88 students engaged in the research. They are from PJHS in Medan, Pematang Siantar, and Percut Sei Tuan. The study is developmental in nature.

Learning material consists of Lesson Plan, students' activity sheets (SAS), Student's Book, MRA-test consisting Pre-test, Post-test (Test-I and Test-II). In addition, Observation and responses sheet and Interview Guidelines are also used. Teaching material constitute of Linear Equation of Two Variables and Pythagorean Theorem. The problems posed in SAS are an important part of learning materials. Most of them as well as the MRA-test are developed by considering some thoughts of Resnick on HOTs. Observation and interview guidelines are set-up based on survey research theory. Last, teaching materials are chosen by considering Indonesian 2013-Curriculum, which is well suited for modified JPBL model.

\subsection{Instruments, Data Collection and Analysis}

MRA-test comprises of two aspects, i.e. (a) Represent word problem into picture, figure, table, graph, or mathematical model as an aid to solve problem; (b) Interpret problem presented in figure, table, graph, mathematical model verbally with supporting explanation. Indicators as the details these aspects set up for measuring the students MRA-test conveyed in Table 2. There were five problems designed and posed to measure the students' MRA for each pre-test and post-test.

Guideline for scoring students' performance in the MRA-test is depicted in Table 3. This rubric is developed by considering Baker (1990) concerning assessing high order thinking.

Table 2. Indicators of MRA

\begin{tabular}{rlc}
\hline Aspect & Indicators & Problem Number \\
\hline & $\begin{array}{l}\text { Create figure to represent word problem at hand } \\
\text { Represent word problem in figure/picture/graph }\end{array}$ & 1 \\
\cline { 2 - 3 } & $\begin{array}{l}\text { Create table as an aid to attain solution } \\
\text { Represent problem in a table as an aid to attain solution }\end{array}$ & 3 \\
\hline & Interpret problem in figure verbally with supporting explanation & 4 \\
\cline { 2 - 3 } (b) & $\begin{array}{l}\text { Create mathematical model as a tool to solve problem } \\
\text { Use mathematical model (equation) to solve problem }\end{array}$ & 2,5 \\
\hline
\end{tabular}


Table 3. Rubric scoring for MRA-Test

\begin{tabular}{lc}
\hline Components of Mathematical Representation & Score \\
\hline Construct appropriate mathematical representation accurately and manipulated it perfectly to get the right solution. & 4 \\
\hline $\begin{array}{l}\text { Construct appropriate mathematical representation accurately and manipulated it perfectly but there are some mistakes in numerical } \\
\text { computing. }\end{array}$ & 3 \\
\hline Construct appropriate mathematical representation but there is not any necessary manipulation to solve problem & 2 \\
\hline $\begin{array}{l}\text { There have been attempts to construct mathematical representation and communicate the problem but failed moving forward the } \\
\text { work }\end{array}$ & 1 \\
\hline No attempt made to construct a mathematical representation for the problem & 0 \\
\hline
\end{tabular}

Observation sheet on instruction is used to record the learning and teaching processes. Using it, we analyze to what extent the degree of the learning materials developed was implemented and to analyze the way of teachers conducted the lessons in the classroom. It comprises of teachers' effort in endorsing students' willingness to learn, directing students to study hardly (keeping perseverance), forcing the students' engagement in discussion to solve problems, encouraging students to do investigation, providing opportunity to students solving problems in different ways and different mathematical representation, endorsing interaction within group-work, and giving necessary scaffolding and guiding reflection activity.

On the other side, observation sheet on students' activities is based on students' involvement in doing math problems, students' participation in-group discussions as well as in classroom, students' activity in responding questions, posing suggestions and critics to others, and students' response towards teacher's direction.

Last, the researchers used responses scale to reveal students and teachers' responses toward and perception to the learning materials developed.

In our developmental research, the intervention is the implementation of instruction materials developed based on Joyful Problem-Based Learning (JPBL). According to Nieveen and Folmer (2013), intervention in instruction is effective if it results in desired outcome. Cai et al. (2009) state "the quality of mathematics instruction can be judged by two criteria: desirable outcomes in students' learning and the processes that yield those desirable learning outcomes". Concerning to the first aspect Nieveen, Folmer, and Cai mention, in their work Napitupulu, Suryadi, and Kusumah (2016) find the highest average score of upper secondary students in mathematical reasoning ability, which is part of HOTs, was 58 of 100 and only achieved by $26 \%$ of the students. Considering the result and the effectiveness criteria they propose, to be judged effective, we determined the desired intervention of our developed instruction materials should fulfil the following criteria:

1) More than $65 \%$ of the students attain minimal score 65 in MRA test (from ideal score 100) and the students' MRA improved significantly.

2) Students' activities while learning, especially in solving mathematical problems, and teachers' activities in teaching process can be classified well, that is $\bar{x} \geq 85$ ( $\bar{x}$ is activity average score).

3) Both students and teachers mark positive perception to and response towards the learning materials that is the average score is greater than 75 .

All data was analyzed descriptively except the improvement of students' MRA, which used t-test to draw conclusion.

\section{Results and Discussion}

\subsection{MRA test, Observation, Perception and Response of Students \& Teachers}

Table 4a presents the students' average score on MRA-test. The table shows a relatively high increasing score from the Pre-test to the Test-1. On the contrary, from Test- 1 to Test-2 the increasing was small. Albeit small, it was very important for it contributed to the more amounts of the students who passed the minimum criteria. 
Table 4a. Average Score on Pre-test, Test-I, and Test-II

\begin{tabular}{lclclcl}
\hline Test & \multicolumn{2}{c}{ PJHS 27 Medan } & \multicolumn{2}{c}{ PJHS 1 Percut } & \multicolumn{2}{c}{ PJHS 7 P. Siantar } \\
\hline & $\overline{\boldsymbol{x}}$ & Percentage & $\overline{\boldsymbol{x}}$ & Percentage & $\overline{\boldsymbol{x}}$ & Percentage \\
\hline Pre-test & 6,74 & 33,70 & 6,96 & 34,80 & 6,89 & 34,45 \\
\hline Test-I & 12,18 & 60,90 & 12,04 & 60,40 & 12,14 & 60,73 \\
\hline Test-II & 13,38 & 66,90 & 13,04 & 65,20 & 13,00 & 65,00 \\
\hline
\end{tabular}

Note. Ideal Score $=20 ;$ Percentage $=$ Ratio between average score and ideal score

Percentage and the number of the students attained minimum score 65 is presented in Table $4 \mathrm{~b}$. It means that part of the first criteria of the effectiveness is fulfilled.

Table 4b. Percentage of the Students Attained Minimum Score

\begin{tabular}{lcccc}
\hline & PJHS 27 & PJHS 1 & PJHS 7 & Overall \\
\hline \# Student & 23 & 17 & 20 & 60 \\
\hline $\mathrm{N}$ & 34 & 26 & 28 & 88 \\
\hline$\%$ & 67.65 & 65.38 & 71.43 & 68.18 \\
\hline
\end{tabular}

Note. Minimum Score $=65$; Ideal Score $=100$

Moreover, the improvement of students' MRA is investigated through the difference score between pre-test to Test-II. Statistical t-test used to draw the significance of the differences. Result of t-test between pre-test and Test-II is significant at 5\% level. It means that the students' MRA improved. Data on the difference score between Pre-test and Test-I is presented in Table 5, while the difference score between Pre-test and Test-II is presented in Table 6. Output of t-test for the difference of test I and pretest as well as for test I and test II is presented in Appendix 2. The test is conducted after test of normality of the data and homogeneity of variance was fulfilled.

Table 5. The MRA score difference between Pre-test and Test-I

\begin{tabular}{ccc}
\hline PJHS 27 Medan & PJHS 1 Percut & PJHS 7 P.Siantar \\
\hline 5.44 & 5.08 & 5.25 \\
\hline
\end{tabular}

Table 6. The score difference between Pre-test and Test-II

\begin{tabular}{ccc}
\hline PJHS 27 Medan & PJHS 1 Percut & PJHS 27 Medan \\
\hline 6.647 & 6.077 & 6.107 \\
\hline
\end{tabular}

The result of observation on the teachers' activity is presented in Table 7, meanwhile on the students' activity is presented in Table 8. From the Table 7, we saw that teachers' activity average score is higher than 85 . At the same time, from Table 10, we got that the students' activity average score is also higher than 85 . In overall, the students engaged actively in the learning and teaching process. In this case, the result exceeded the target has been set for the second effectiveness criteria.

Table 7. Percentage of teachers' activity in learning process

\begin{tabular}{llc}
\hline No. & Teachers' Activity & Average Percentage \\
\hline I & The teacher use contextual problems in learning & 91.67 \\
II & The teacher lead students to construct knowledge & 87.85 \\
III & The teacher use scaffolding to help students solve problems & 88.03 \\
IV & The teacher build learning communities & 97.23 \\
V & The teacher assess authentically and encourage the students to reflect their work & 91.28 \\
& Average & 91.21 \\
\hline
\end{tabular}


Table 8. Percentage of students' activity in doing SAS on MRA problems

\begin{tabular}{llc}
\hline No & Students' activity & Percentage \\
\hline 1 & Sharing ideas to group partners while group discussing & 90.2 \\
2 & Sharing ideas while classroom discussing & 85.7 \\
3 & Ask teacher/other group when his group get stuck & 80.3 \\
4 & Ask teacher when classroom discussion & 90.4 \\
5 & Posing different idea while group discussion & 85.7 \\
6 & Posing different idea while classroom discussion & 80.1 \\
7 & Answering teacher's or other's while classroom discussion & 95.3 \\
8 & Pose suggestion while classroom discussion & 86.7 \\
9 & Pay attention to other group work when presented & 93.5 \\
10 & Try other method in solving problem & 90.0 \\
11 & Posing question which need explanation & 90.2 \\
12 & Posing “yes" or "no" question & 85.7 \\
& Average & 87.82 \\
\hline
\end{tabular}

The scale on students and teachers' perception to and response toward the learning materials developed revealed the average score is 83.9. In consequence, the data fulfilled the third criteria of the effectiveness accordingly. To sum up, from the objective viewpoint the instruction materials developed is effective. It implies that the learning devices is eligible used at a wider scope (disseminate) (Nieveen \& Folmer, 2013).

\subsection{Students' Performance in Learning Process}

We investigated Students' performance during the learning process by analyzing their work on the problems in the SAS. Examples of the problems showed in Table 9. An example of full SAS attached in Appendix 1.

Table 9. Examples of problems in SAS

\begin{tabular}{|c|c|c|}
\hline No & \multicolumn{2}{|c|}{ Problem } \\
\hline \multirow[t]{8}{*}{1} & \multicolumn{2}{|c|}{ From The center of Baby Health, we obtained the following data, which explained the growth weight of a baby. } \\
\hline & Baby's age (months) & Weight (g) \\
\hline & 1 & 3000 \\
\hline & 2 & 3300 \\
\hline & 3 & 3600 \\
\hline & 4 & 3900 \\
\hline & Based on the data, determine: & a. The weight of a baby at age 10 . \\
\hline & \multicolumn{2}{|c|}{ b. Mathematical model that represent the relationship between age and weight. } \\
\hline 2 & \multicolumn{2}{|c|}{$\begin{array}{l}\text { At a strait, a swimmer started to swim as far as } 3000 \mathrm{~m} \text { straight. Then, he went on swimming to left as far } \\
\text { as } 4000 \mathrm{~m} \text {. Determine the distance (in meter) if he directly swam from the starting point to the end position. }\end{array}$} \\
\hline
\end{tabular}




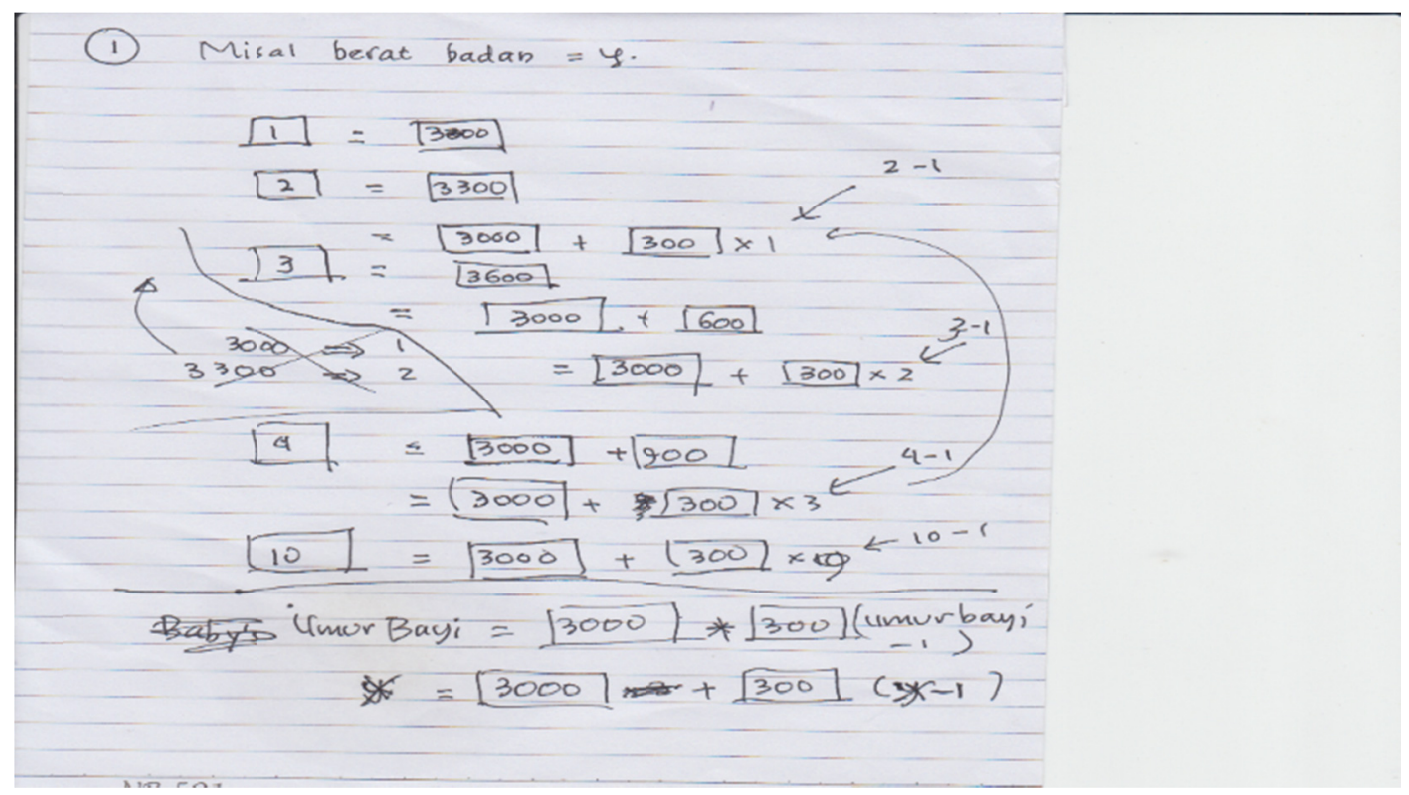

Figure 1. Problem: Weight of a baby

One group's performance in solving problem number 1 is showed in Figure 1. It revealed that the group confused between weight and age of the baby, even though they were capable to manipulate the equation. After having received teacher's scaffolding, they ameliorated their work and solved the problem correctly as shown in Figure 2.

For problem number 2, students performed an interesting solution, as depicted in Figure 3. As we observe Figure 3 , the students previously were not aware of the Pythagorean formula they wrote. Teacher warned them on it, they then ameliorated by putting the square sign on $J(J=$ distance $)$. Moreover, they did not directly represent the unit from meter into kilometer to make it easier to handle. Consequently, they then stopped, did not know what to do. Teacher then scaffold by suggesting them comparing what they faced to a specific situation. That is a right triangle with the two sides at the right angle has measure 3 and 4. Having had this scaffold, they then continued working as shown in Figure 3. Many students committed this mistake, it pointed out that they had still barrier to exchange one representation to another.

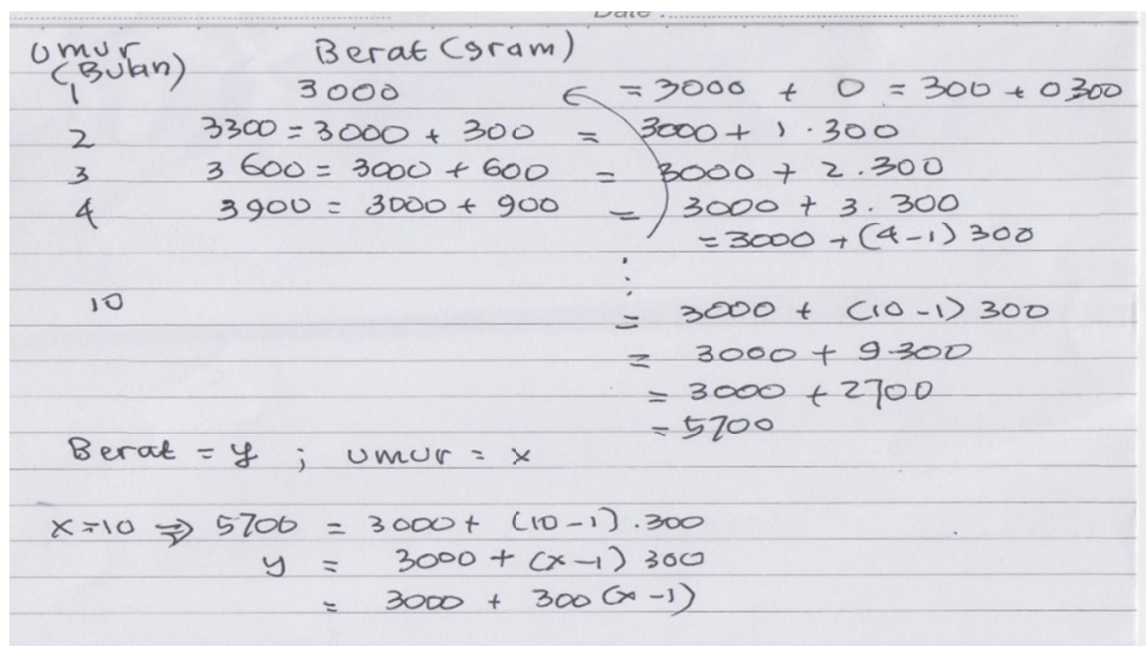

Figure 2. Problem: Baby weight 


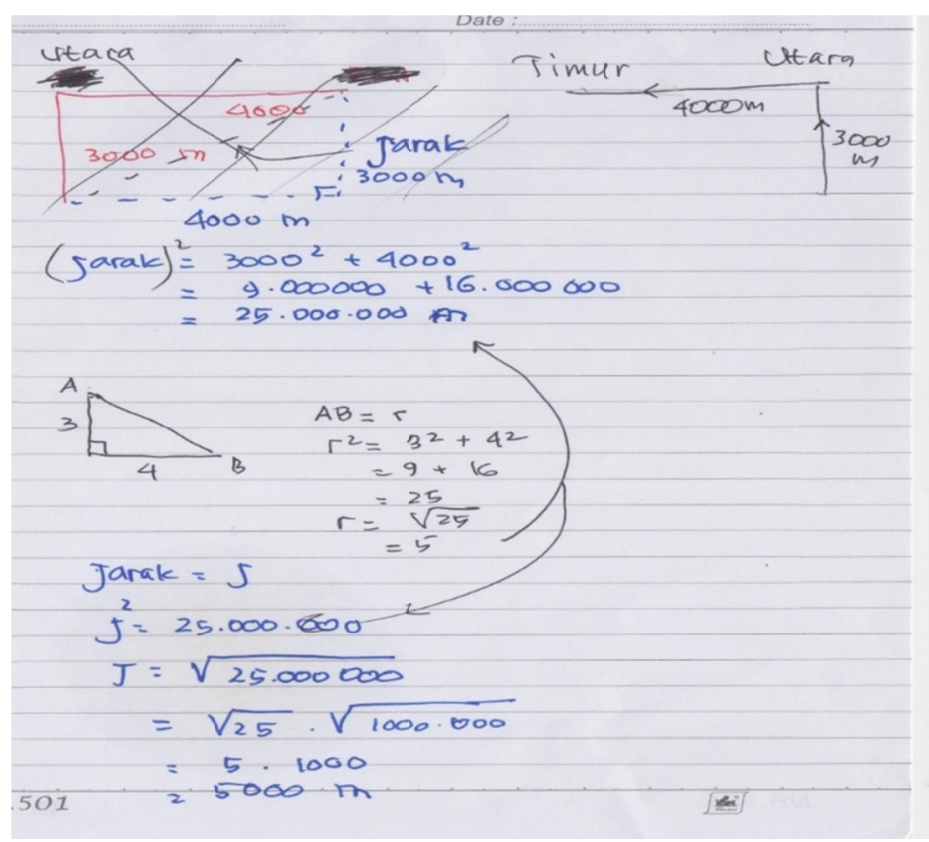

Figure 3. Problem: Distance

Along the learning processes, which passing the lesson by solving problem using various representation continuously, it could be then expected that the students' MRA enhanced.

\subsection{Students' Performance in MRA Pre-test, Test-I, and Test-II}

\section{Pre-test Problem}

1. Look at the picture below. $\overleftrightarrow{A C}$ and $\overleftrightarrow{B D}$ are two lines which intersect at point $\mathrm{O}$. Express an equation which can be used to determine the measure of $\angle B O C$.

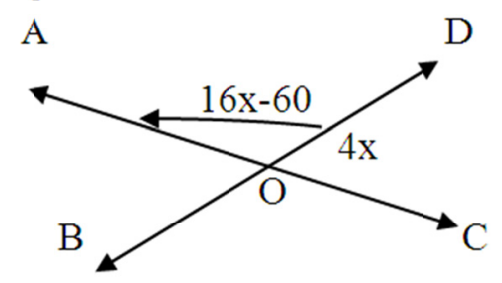

2. Draw a line passes through the points $(-2,0)$ and $(-2,3)$ on a Cartesian Plane. Then draw another which is perpendicular to it.

Problem number 1 is intended to measure the ability to create a mathematics equation from a given picture. Figure 4 showed the student was not aware of the concept of supplementary angle to exhibit a simple relationship between angles, which will lead him to the equation demanded.

For problem number 2, less than a quarter of the students completed this task. More than a half of them have forgotten the concept of drawing line through two points. Some of them plot -2 at $x-$ axis and 0 at $y-$ axis, then connected them to draw a line as representation of point $(-2,0)$. It seems as if it is impossible, but it is a fact. 


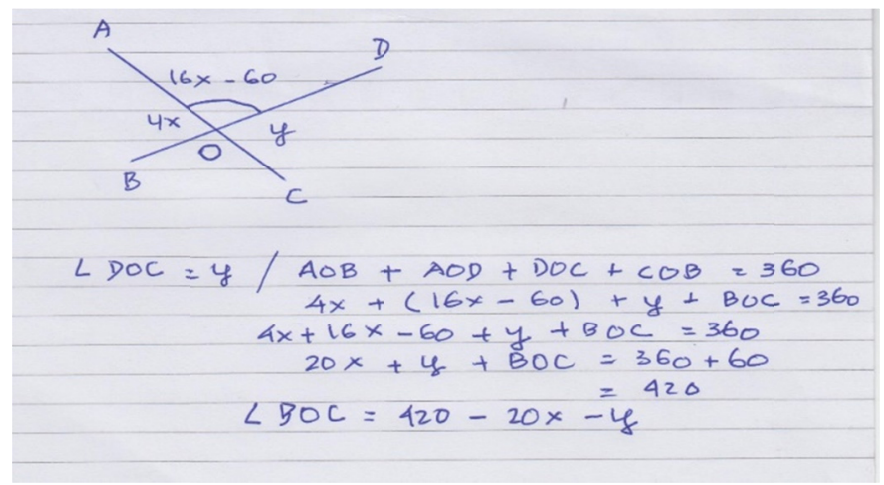

Figure 4. Measuring an angle

Next are two problems of Test- II. One of Student's performances on problem 1 is depicted in Figure 5. Problem number 1 aimed to elicit students' ability to draw lines as the trajectory of travelling ants. The figure displayed showed that the student understood what to do. He put first two points of each line on the Cartesian plane then connected them to form the line. To the end, he concluded that the intersection of the lines to be the point where the both ants met. This confirmed that after experiencing the intervention that is the implementation of the learning materials, growth in mathematical representation ability occurred in the part of the students.

\section{Test-II problems}

1. Suppose the trajectory of a travelling ant is represented by equation $y=-x+5$.

Another one passed the track $y=x+5$. Draw the graph of the trajectories. Determine the point where both ants met.

2. Sophia got $\$ 5$ for each passed subject exam in school, but should return $\$ 10$ for failed.

After completing the entire test, Sophia succeeded four times as she failed, and gained $\$ 60$.

Determine in how many subjects she succeeded.

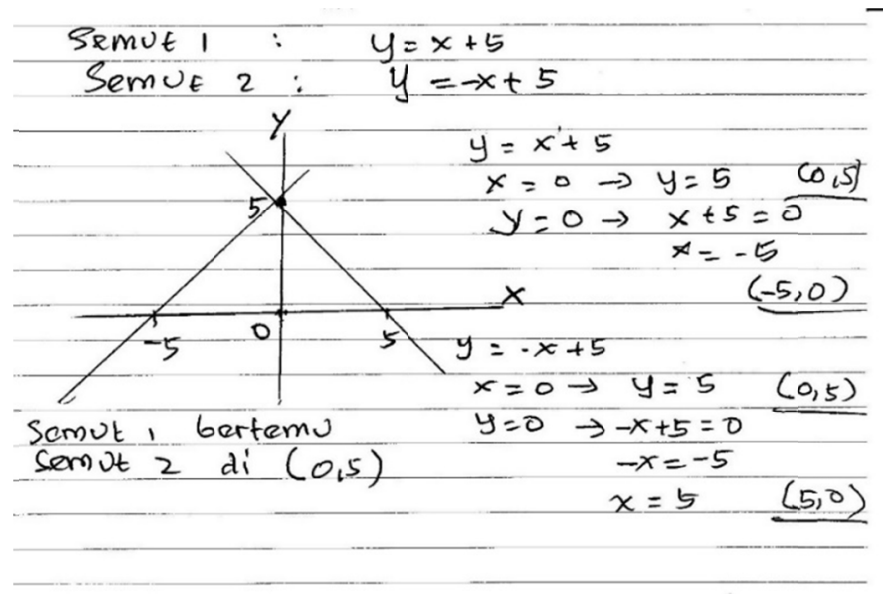

Figure 5. Problem: Trajectory of traveling ant

The 88 students engaged in the research performed vary solutions to each problem. The different solutions were not always all true, but at least, they have tried representing what they understood from the problem. One different solution for problem number 1 on trajectory of traveling ants emerged in Figure 6. This student did not draw the lines and focused only to the demand on determining the coordinate where the ants met. Interview then revealed that he was exhausted for firstly working consecutively on number 2 up to number 5 then returned to number 1 . 


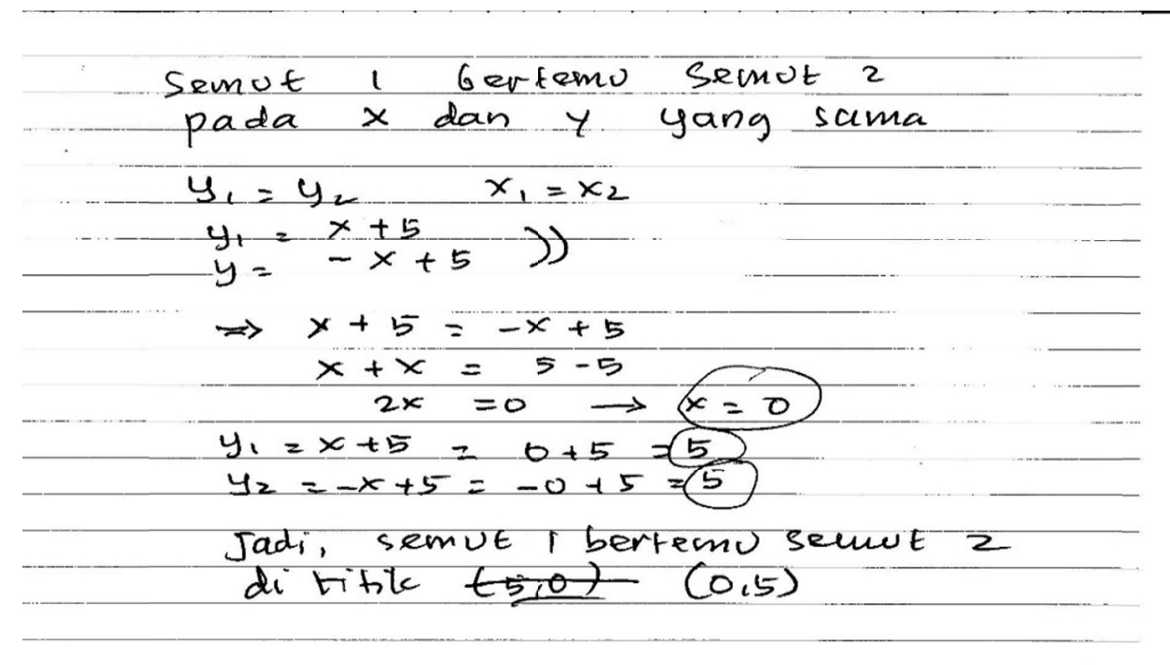

Figure 6. A student's answer to the traveling ant problem

Problem number 2 requires the students' ability to represent the problem into mathematical model as a bridge to aid them reaches the solution. Two students' works picked in Figure $7 \mathrm{a}$ and $7 \mathrm{~b}$ demonstrated different comprehension thus representation on the problem. The first work sheet (Figure 7a) revealed that the student was incapable to engage all the information given into the mathematics equation demanded. He neither considering reward for success nor penalty for failed in the equation. Moreover, instead of subtracted penalty of failure to the reward of success, he summed up both. The advantage that was able to represent 'successes' as $x$-variable and represent 'failed' as $y$-variable. This is a significant progress for a student with low mathematical prior knowledge and low representation ability. Though at the end of the work emerged an attempt to check the truth of his answer, but he stopped without any effort to ameliorate it.

On the contrary, the second work sheet (Figure 7b) showed one's understanding how to represent the problem into a mathematics equation and obtaining a system of linear equations of two variables. It continued showing the ability to use substitution technique to solve the problem and finally got the solution.

In overall, the mean score of students' MRA in Test-II is significantly higher in comparing to their Pre-Test score. This proved that the using of the learning materials developed based on JPBL implied the increasing of the students' MRA in some districts in the Province of North Sumatera.

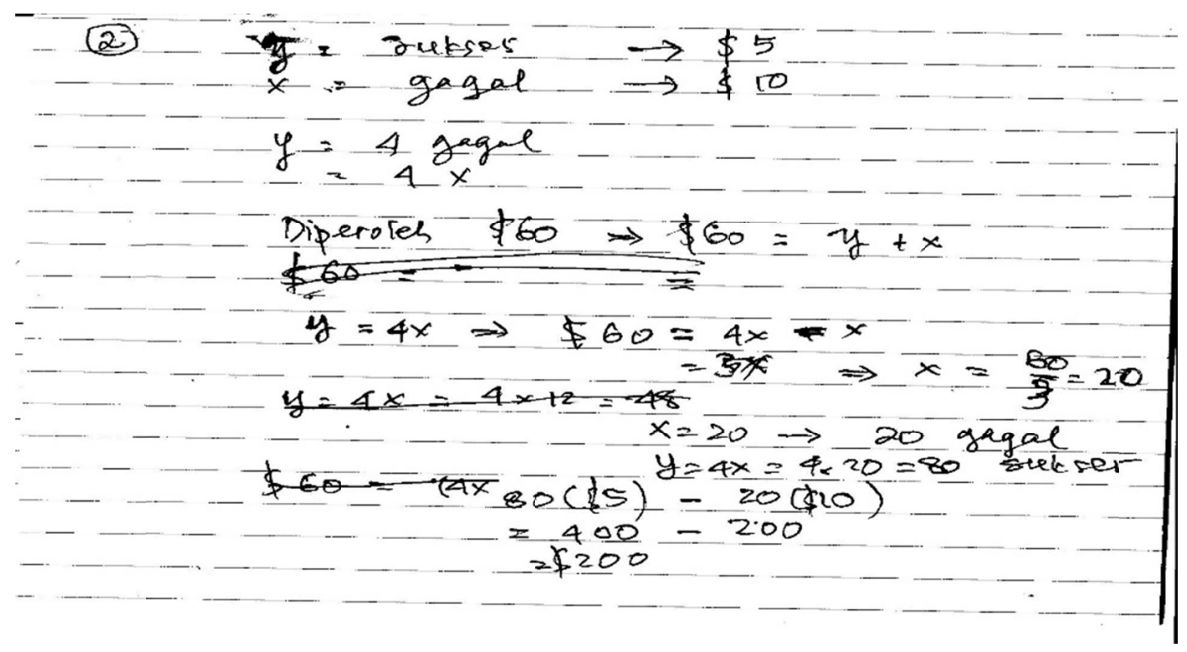

Figure 7a. Reward for success problem 


\begin{tabular}{|c|c|}
\hline \multicolumn{2}{|r|}{ Date: } \\
\hline 2) & $x=$ sukses,$\quad y=g a g a l \mid x \rightarrow \$ 5$ \\
\hline & $x=4 y$ \\
\hline & $\Rightarrow 60=$ sucses - gagal \\
\hline & $=5 x-10 y$ \\
\hline & $=5(4 y)-10 y$ \\
\hline & $=20 y-10 y$ \\
\hline & $=10 y \rightarrow y=\frac{60}{10}=6$ \\
\hline & gagal 6 kall \\
\hline & suleses $4 \times 6=24$ \\
\hline & $60=5(24)-10(6)$ \\
\hline & $z 120-60$ \\
\hline & $=60$ \\
\hline
\end{tabular}

Figure 7b. Another student's answer on the traveling ant problem

\subsection{Students' Performance in Each Aspect of MRA Test}

The average score for each indicator of the students' MRA in Test-I was presented in Table 10. Indicator 1 and 2 is the aspect of the ability of representing word problem in picture, figure, table, or symbol. Indicator 3 is the aspect of the ability to interpret problem in figure verbally with supporting explanation. Indicator 4 and 5 is the aspect of ability to use representation such as figure/picture or mathematics model/equation to solve problem.

Table 10. Average score of each MRA indicator

\begin{tabular}{lccccc}
\hline \multirow{2}{*}{ School } & \multicolumn{5}{c}{ Indicator } \\
\cline { 2 - 6 } & 1 & 2 & 3 & 4 & 5 \\
\hline PJHS 27 & 2.26 & 2.44 & 2.44 & 2.62 & 2.24 \\
PJHS Percut & 2.73 & 2.35 & 2.73 & 2.23 & 2.04 \\
PJHS Siantar & 2.79 & 2.18 & 2.57 & 2.29 & 2.21 \\
\hline
\end{tabular}

Note. Ideal score $=4$.

It can be concluded that the students most powerful is in the aspect of interpret problem in figure verbally with supporting explanation. The result we obtained in this study prove that teaching and learning processes which continuously ask students pose various representation of mathematical problems will enable them improving their mathematical representation ability. This result is in line with what Meira (2002) and Pape \& Tchoshanov (2001) have established. In addition, it supports the goals of learning mathematics NCTM (2000) declared.

\section{Conclusion}

The instruction materials we developed in this study succeeded achieving its intention. It fulfills the desired outcomes. As mentioned earlier, the desired outcomes are: (1) Overall, 68.18\% of the students attain minimal score 65 in MRA test (from ideal score 100) and the students' MRA improved significantly; (2) Students' activities while learning, especially in solving mathematical problems, and teachers' activities in teaching process can be classified well; and (3) Both students and teachers mark positive perception to and response towards the instruction materials.

\section{Acknowledgments}

This research was supported by the Ministry of Research, Technology and Higher Education of the Republic of Indonesia. The authors are thankful to Rector of State University of Medan, Research Director, and Dean of Faculty of Mathematics and Natural Sciences for providing necessary facilities to conduct the research.

\section{References}

Arends, R. I. (2004). Learning to Teach (6th ed.). New York: The McGraw-Hill Company, Inc.

Baker, E. L. (1990). Developing Comprehensive Assessments of Higher Order Thinking. In G. Kulm (Ed.), Assessing High Order Thinking in Mathematics. Washington DC: American Association for the 
Advancement of Science.

Cai, J. (2009). What is Effective Teaching? A Study of Experienced Mathematics Teachers from Australia, the Mainland China, Hong Kong-China, and the United States. In J. Cai, G. Kaiser, B. Perry, \& N.-Y. Wong (Eds.), Effective Mathematics Teaching from Teachers'Perspectives. Rotterdam: Sense Publisher.

Carpenter, T. P., \& Lehrer, R. (1999). Teaching and Learning Mathematics with Understanding. In E. Fennema, \& T. A. Romberg (Ed.), Mathematics Classrooms that Promote Understanding. Mahwah: Lawrence Erlbaum Associates, Inc.

Cobb, P., Yackel, E., \& Wood, T. (1992). A Constructivist Alternative to the Representational View of Mind in Mathematics Education. Journal for Research in Mathematics Education, 23(1), 2-33. https://doi.org/10.2307/749161

Fogarty, R. (1997). PBL and Other Curriculum Models for the Multiple Intelligence Classroom. Melbourne, Vic: Hawker Bronlow Education.

Goldin, G. A. (2002). Representation in mathematical learning and problem solving. In L. D. English (Ed.), Handbook of international research in mathematics education (pp. 197-218). Mahwah, NJ: Lawrence Erlbaum Associates, Publishers.

Hmelo, C. E., \& Ferrari, M. (1997). The Problem-Based Learning Tutorial: Cultivating Higher Order Thinking Skills. Journal for the Education of the Gifted, 20(4). https://doi.org/10.1177/016235329702000405

Kilpatrick, J., Swafford, J., \& Findell, B. (2001). Adding It Up: Helping Children Learn Mathematics. Washington DC: National Academy Press.

Kulm, G. (1990). Assessing High Order Thinking Mathematical Thinking: What We Need to Know and Be Able to Do. In G. Kulm (Ed.), Assessing High Order Thinking in Mathematics. Washington DC: AAAS Publication.

Meira, L. (2002). Mathematical Representation as System of Natation-in-use. In Gravemeijer et al. (Eds.), Symbolizing, Modelling and Tool Use in Mathematics Education. Dordrecht: Kluwer Academic Publisher.

Minarni, A., Napitupulu, E. E., \& Husein, R. (2016). Mathematical Understanding and Representation Ability of Public Junior High School in North Sumatera. Journal on Mathematics Education, 7(1), 43-56. https://doi.org/10.22342/jme.7.1.2816.43-56

Napitupulu, E. E., Suryadi, D., \& Kusumah, Y. S. (2016). Cultivating Upper Secondary Students' Mathematical Reasoning Ability and Attitude towards Mathematics through Problem-Based Learning. Journal on Mathematics Education, 7(2), 117-128. https://doi.org/10.22342/jme.7.2.3542.117-128

NCTM. (1989). Curriculum and Evaluation Standards for School Mathematics. Reston, VA: NCTM.

NCTM. (2000). Principle and Standards for School Mathematics. Reston, VA: NCTM.

Nieveen, N., \& Folmer, E. (2013). Formative Evaluation in Educational Design Research. In Plomp, \& Nieveen (Eds.), Educational Design Research. Enschede: SLO.

Pape, S. J., \& Tchosanov, M. A. (2001). The Role of Representation(s) in Developing Mathematical Understanding. Theory into Practice, 40(2), 118-127. https://doi.org/10.1207/s15430421tip4002_6

Plomp, T. (2013). Educational Design Research: An Introduction. In Plomp, \& Nieveen (Eds.), Educational Design Research. Enschede: SLO.

Puri, A. (2014). How to Create Joyful Learning in the Classroom. Retrieved from https://www.howtolearn.com

Resnick, L. B. (1987). Education and Learning to Think. Washington DC: National Academic Press.

Ronis, D. L. (2008). Problem-based Learning for Math \& Science; Integrating Inquiry and the Internet. California: Corwin Press.

Saragih, S., \& Napitupulu, E. E. (2015). Developing Student-Centred Learning Model to Improve High Order Mathematical Thinking Ability. International Education Studies, 8(6), $104-112$. https://doi.org/10.5539/ies.v8n6p104

Schöenfeld, (2007). Reflection on an Assessment Interview: What a Close Look at Student Understanding Can Reveal. In A. H. Schöenfeld (Ed.), Assessing Mathematical Proficiency. New York: Mathematical Sciences Research Institute. 


\section{Appendix 1.}

\section{An Example of Student Activity Sheet (SAS)}
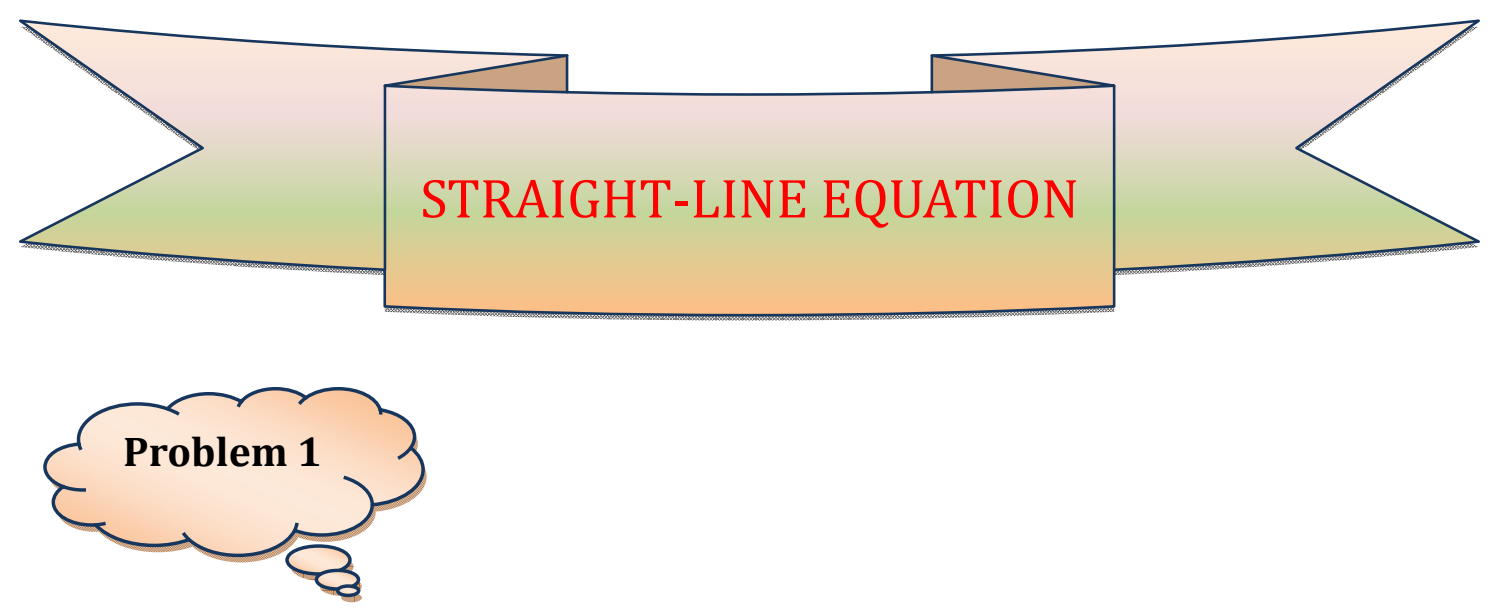

Data from a Community Health Center showed the weight growth of a baby as presented in the table below.

\begin{tabular}{|c|c|}
\hline Baby's age (month) & Weight (gram) \\
\hline 1 & 3000 \\
\hline 2 & 3300 \\
\hline 3 & 3600 \\
\hline 4 & 3900 \\
\hline
\end{tabular}

a. If $x$ constitutes its age and $y$ its weight, construct an equation represents the relationship between $x$ and $y$.

b. What is the baby's weight at the tenth month?

\section{Answer:}

\section{Problem 2}


The following table shows the charge should be paid when using a certain taxi to travel.

\begin{tabular}{|c|c|}
\hline Distance (in km) & Charge (in Rupiah) \\
\hline 0 & 3,000 \\
\hline 1 & 8,000 \\
\hline 2 & 13,000 \\
\hline 3 & 18,000 \\
\hline 4 & 23,000 \\
\hline$\ldots$. & $\ldots \ldots$ \\
\hline 10 & 53,000 \\
\hline$\ldots \ldots$ & $\ldots$. \\
\hline $\mathrm{N}$ & $\ldots \ldots$ \\
\hline
\end{tabular}

1. Determine a mathematics equation which governs the data.

2. Determine the charge if one travels $30 \mathrm{~km}$.

3. What is the mathematical term for the equation you got?
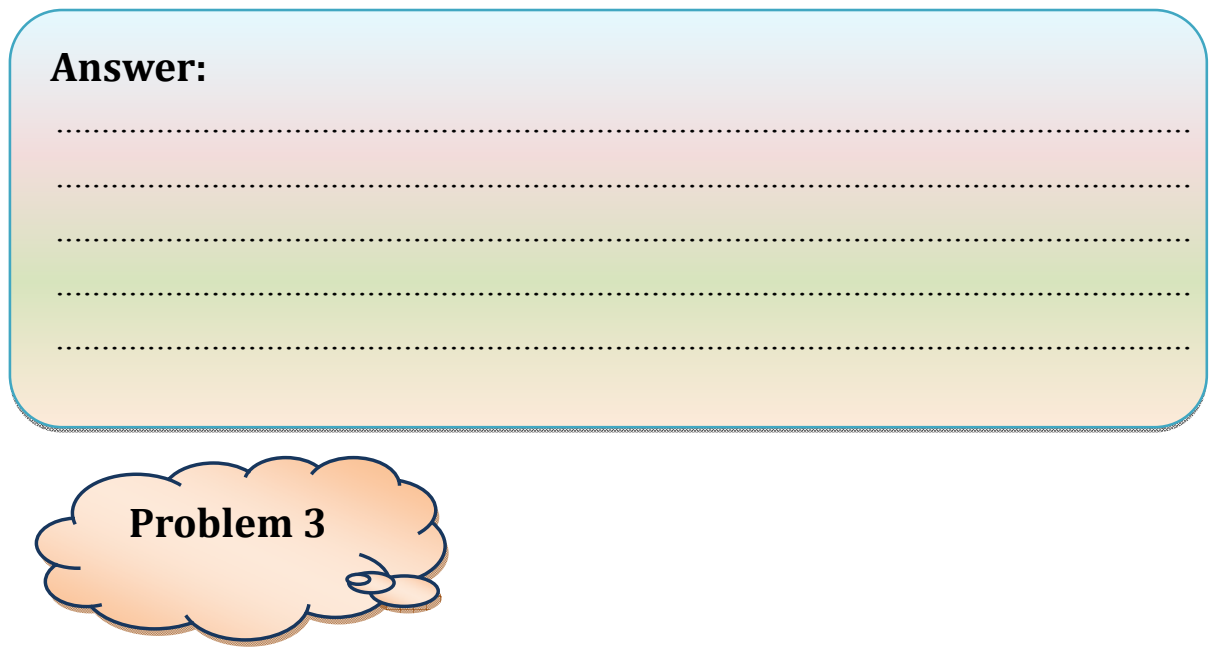

Observe the following number sequence:

$\begin{array}{llllll}0 & 1 & 2 & 3 & \ldots & 13 \\ 50 & 47 & 44 & 41 & \ldots & 1\end{array}$

Determine a mathematics equation which reveals the relationship between the first and the second row.

\section{Answer:}




\section{Conclusion}

Generally, a straight-line equation is expressed by $y=$

At the equation, $x$ and $y$ are called

While $m$ is called and $c$ is called

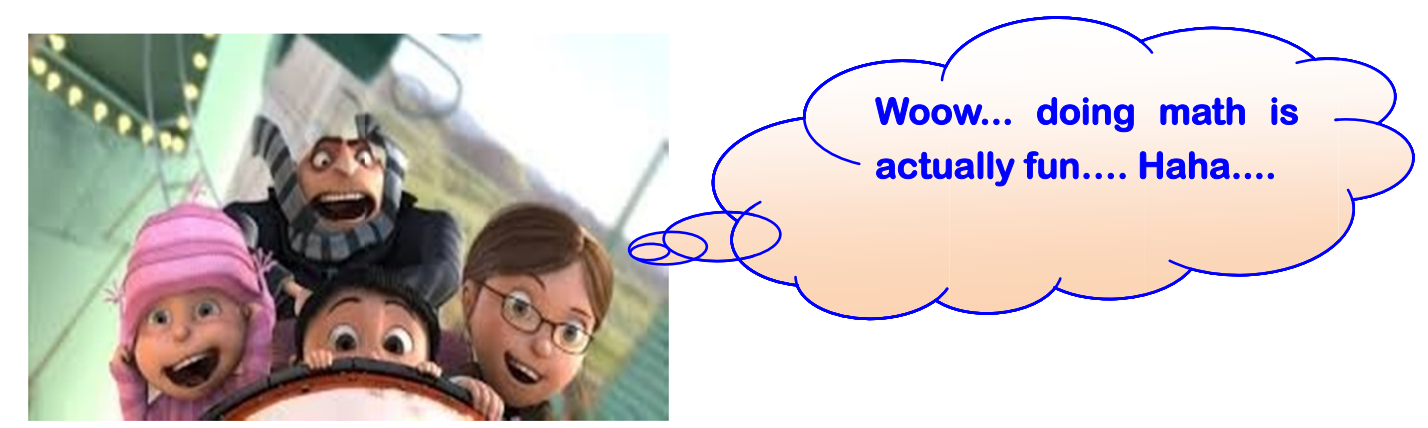

\section{Appendix 2}

\section{Output of t-Test for MRA Score}

\begin{tabular}{|c|c|c|c|c|c|c|}
\hline & \multicolumn{2}{|c|}{$\begin{array}{c}\text { Levene's Test for } \\
\text { Equality of Variances }\end{array}$} & \multicolumn{4}{|c|}{ t-test for Equality of Means } \\
\hline School & F & Sig. & T & df & Sig.2-tailed & $\begin{array}{c}\text { Mean } \\
\text { Difference }\end{array}$ \\
\hline PJHS 27 & 1.313 & .256 & 14.474 & 66 & .000 & 6.647 \\
\hline PJHS 1 & 6.602 & .013 & 10.797 & 50 & .000 & 6.077 \\
\hline PJHS 7 & .072 & .789 & 13.330 & 54 & .000 & 6.107 \\
\hline
\end{tabular}

\section{Copyrights}

Copyright for this article is retained by the author(s), with first publication rights granted to the journal.

This is an open-access article distributed under the terms and conditions of the Creative Commons Attribution license (http://creativecommons.org/licenses/by/4.0/). 